\title{
PROCEEDINGS OF THE THIRTY-THIRD ANNUAL MEETING
}

\author{
BY HAROLD F. MAYFIELD, SECRETARY
}

The Thirty-third Annual Meeting of the Wilson Ornithological Club was held at the Greystone Playhouse, Gatlinburg, Tennessee, on Friday and Saturday, April 25 and 26, 1952. It was sponsored by the Tennessee Ornithological Society, Georgia Ornithological Society, and Carolina Bird Club.

There were four sessions devoted to papers, an evening program of motion pictures, and two general business meetings. A meeting of the Executive Council was held on the evening of April 24. After the motion picture session on Friday evening, members and guests were entertained at a reception by the Tennessee Ornithological Society. A registration fee of $\$ 1.00$ was charged.

The Annual Banquet was held on Saturday evening, with President Maurice Graham Brooks serving as toastmaster and speaker. Local entertainment was provided.

Informal field trips were held Friday morning, and guided field trips Saturday morning and all day Sunday. The sessions on Friday and Saturday began in mid-morning to permit the maximum time afield.

\section{First Business Session}

President Brooks called to order the first general meeting at 10 a.m., Friday, April 25. The minutes of the $32 \mathrm{nd}$ annual meeting were approved as published in the Wilson Bulletin for September, 1951. The report of the treasurer, Leonard C. Brecher, was presented and approved by the membership.

\section{Secretary's Report}

The secretary, Harold Mayfield, reported that the amendment to the constitution submitted to the members by mail ballot in 1951 was passed. This amendment eliminated the associate class of membership, with the effect of increasing the minimum cost of membership to $\$ 3.00$.

The secretary summarized the principal actions of the Executive Council as follows:

1. Harrison B. Tordoff of the University of Kansas was unanimously re-elected editor of The Wilson Bulletin for 1952.

2. The Executive Council accepted the invitation of the University of Michigan and the Michigan Audubon Society to hold the 34th Annual Meeting at the Biological Station near Cheboygan, Michigan, on Friday and Saturday, June 12 and 13, 1953. A meeting of the Executive Council will be held on June 11 and organized field trips will be offered on Sunday, June 14.

\section{Treasurer's Report}

The treasurer, Leonard C. Brecher, reported on the finances of the club. His report was approved, subject to the report of the Auditing Committee scheduled for the following day. A summary of this report appeared in the June, 1952, issue of the Bulletin.

\section{Library Committee}

George Wallace, chairman, reported that accessions to the Library since the last annual 
meeting include 44 books, 365 reprints, 78 magazines and bulletins, and 35 pamphletsa total of 522 items. The leading donors of the year were Margaret M. Nice and Nada Kramer. Members of the club are borrowing books by mail at an increasing rate each year.

\section{Illustrations Committee}

Robert M. Mengel, chairman, reported that the committee is continuing its service to authors who want finished drawings prepared from sketches. This work will be done by the committee at a charge of $\$ 1$ per hour, with the money going to the color-plate fund of the Bulletin.

\section{Conservation Committee}

Robert A. McCabe, chairman, reported by letter that the Conservation Committee has published articles in the Bulletin for September 1951, and March 1952. Other articles are to appear in later issues.

\section{Louis Agassiz Fuertes Research Grant Committee}

Ernst Mayr, reporting for Chairman John Emlen and the committee, stated that the committee's selection for the 1952 grant was Robert W. Nero of the University of Wisconsin, who is working on "Territorial and Sexual Behavior in the Red-winged Blackbird."

\section{Membership Committee}

Ralph M. Edeburn, chairman, reported that the names of 207 prospective members enrolled since the 1951 Annual Meeting were posted for the inspection of members and for election by vote at the final business session. On April 15, 1952, the club had 1788 members and 155 institutional subscriptions to the Bulletin. The membership has continued to grow even though the elimination of the associate membership class has raised the minimum cost of membership.

\section{Temporary Committees}

The President appointed three temporary committees as follows: Auditing Committee

Frederick V. Hebard, Chairman

Burt L. Monroe

Mrs. Herbert E. Carnes

Resolutions Committee

Richard H. Pough, Chairman

Zeno P. Metcalf

Ben Coffey, Jr.

Nominating Committee

O. S. Pettingill, Jr., Chairman

A. W. Schorger

R. Allyn Moser

\section{Second Business Session}

The second and final general business meeting was called to order at 10 a.m., Saturday, April 26, by President Brooks. 
The applicants for membership, whose names were posted in the reception area, were elected to the club.

\section{Report of Auditing Committee}

The Auditing Committee reported that the books of the treasurer had been examined and found to be in excellent order. Special thanks were expressed to Burt Monroe for the special assistance he had given the new treasurer at the start of the year.

\section{Report of Resolutions Committee}

WHEREAS variations in the intensity of solar ultraviolet appear to have a significant influence on many organisms including birds, BE IT RESOLVED that the Wilson Ornithological Club urge the United States Weather Bureau to give increased attention to accurate recording of such variations.

BE IT RESOLVED that the Wilson Ornithological Club express its great appreciation to the officials of the Great Smoky Mountains National Park for all the things they have done to make this meeting and the field trips successful.

BE IT RESOLVED that the Wilson Ornithological Club express its sincere thanks to the Gatlinburg Chamber of Commerce and the Greystone Hotel for the facilities that have been made available during these meetings and for the many advance arrangements that have contributed so greatly to the comfort of those attending.

BE IT RESOLVED that the Wilson Ornithological Club tender its wholehearted thanks to Arthur Stupka and the other members of the local committee for the time and thought that went into the arrangements which have made this meeting such an outstanding success as a scientific and social gathering and as a unique field experience for so many of us.

BE IT RESOLVED that the Wilson Ornithological Club express its appreciation to Gretchen and Bill Postlewaite of the Gatlinburg Press for the fine publicity they have given this meeting in this week's issue of the Press.

\section{Election of Officers}

Olin Sewall Pettingill, Jr., reported for the Nominating Committee and proposed the following members for officers in 1952: President, Walter J. Breckenridge; First Vice President, Burt L. Monroe; Second Vice President, Harold F. Mayfield; Treasurer, Leonard C. Brecher; Secretary, Phillips B. Street; Elective members of Executive Council, Fred T. Hall (term expires 1953), W. W. H. Gunn (term expires 1954), Joseph C. Howell (term expires 1955) .

The report of the Nominating Committee was accepted, and the secretary was instructed to cast a unanimous ballot for these nominees.

\section{Papers Sessions \\ Friday, April 25}

Arthur Stupka, U. S. National Park Service, Some Natural History Features of Great Smoky Mountains National Park, slides.

V. E. Shelford, University of Illinois, An Experimental Approach to the Study of Bird Populations, slides.

Harrison B. Tordoff, University of Kansas, The Relationships of the "Fringillid" Subfamily Carduelinae, slides. 
Ernst Mayr, American Museum of Natural History, Problems of Bird Systematics.

Eugene P. Odum, University of Georgia, Seasonal Periodicity in Fat Deposition in Birds, slides.

Nicholas Cuthbert, Central Michigan College, Food Requirements of the Black Tern, slides.

Josselyn Van Tyne, University of Michigan, Systematic Records on Bird Nests, slides.

Charles H. Blake, Massachusetts Institute of Technology, Birds and W aves, slides.

Margaret Morse Nice, Chicago, Illinois, Concerning Incubation Periods.

Aretas A. Saunders, Canaan, Connecticut, Variations in the Songs of the Purple Finch.

James H. Jenkins, University of Georgia, Distribution and Abundance of the Wild Turkey in Georgia, slides.

Ralph Edeburn, Marshall College, Activities at a Nighthawk's Nest, motion pictures.

Douglas E. Wade, Clemson Agricultural College, Pileated Woodpecker and Horned Grebe, motion pictures.

Karl Maslowski, Cincinnati, Ohio, Earthquake Lake, motion pictures.

\section{Saturday, April 26}

Olin Sewall Pettingill, Jr., Carleton College, Ornithologically Unexplored Areas of the United States, slides.

Thomas L. Quay, North Carolina State College, Habitat and Territory in Macgillivray's Seaside Sparrow, slides.

Chandler S. Robbins, U. S. Fish and Wildlife Service, Cooperative Fall Migration Studies on the Broad-winged Hawk in 1951, slides.

Edward L. Seeber, Marshall College, The Changing Waterfowl Populations in the Central Ohio Valley.

Arthur Stupka, U. S. National Park Service, Some Notes Relating to the Mortality of Screech Owls in Great Smoky Mountains National Park.

Haven H. Spencer, Ann Arbor, Michigan, The 1951-52 Winter Invasion of Boreal Bird Forms in Michigan.

James T. Tanner, University of Tennessee, Survival Rates of Passerine Birds, slides.

Joseph C. Howell, University of Tennessee, A Population Index for the Bald Eagle in East Central Florida.

Harold S. Peters, U. S. Fish and Wildlife Service, The Cooperative Mourning Dove Study. Kenneth C. Parkes, Cornell University, The Sharp-tailed Sparrow in New York: A Reevaluation of the Races, slides.

Frederick V. Hebard, Philadelphia, Pennsylvania, The Warblers of Southeastern Georgia.

\section{ATTENDANCE}

Members and guests registered at the meeting numbered 359. They came from 26 states and one province of Canada.

From Alabama: 3-Birmingham, Mrs. Blanche E. Dean, Mrs. John H. Williamson; Fairfield, Thomas A. Imhof.

From California: 2-San Francisco, Maxine Chenoweth, Paul Chenoweth.

From Connecticut: 2-Canaan, Aretas A. Saunders; New Haven, Mrs. Doris Lehman.

From District of Columbia: 3-Washington, Allen J. Duvall, Mr. and Mrs. C. O.

Handley, Jr. 
From Florida : 4-Daytona Beach, Mr. and Mrs. C. H. Ekdahl; Ponca City, Mr. and Mrs. Joe C. Creager.

From Georgia: 63-Athens, J. H. Jenkins, Gibson Johnston, Sr., Jim Major, Eugene P. Odum, Bob Pearson; Atlanta, Ann F. Anderson, Dr. Sam A. Anderson, Orpha P. Baker, Mr. and Mrs. George Beal, Mrs. J. E. Boyd, Beverly Brown, Rebecca Brown, Mrs. J. M. Candlish, Mrs. Charles G. Cowan, Gertrude C. Werner, Ray C. Werner, Mrs. J. C. Olins, Mr. and Mrs. Richard A. Parks, Mrs. E. R. Partridge, Fay S. Peters, Harold S. Peters, Ralph L. Ramsey, Cleo Sampson, Mrs. J. Morgan Smith, Mr. and Mrs. W. J. Snow, Mrs. Frances Stafford, Eva M. Stokely, Mrs. B. H. Willinghorn; Augusta, J. Fred Denton, Mrs. Gary Satcher; Collegeboro, Gilbert C. Hughes, III, Jimmy Oliver; College Park, Mr. and Mrs. William W. Griffin; Columbus, T. Charlton Hudson, Mrs. Frank Schley; Dalton, Blanche Gardner, Mr. and Mrs. R. E. Hamilton; Decatur, J. B. Ross; Demorest, Dorothy P. Neal; Folleston, Frederick V. Hebard; Macon, Edmund Farrar, Jr.; Marietta, Manella B. Laud, Mary Phillips; Milledgeville, Mrs. Fern E. Davis, Gertrude Manchester, Mrs. Lucille C. Rutchford, Gloria Vicedomini; Richmond Hill, Sam Miller; Robins A.F. B., Nathaniel R. Whitney, Jr.; Savannah, Mr. and Mrs. Herman W. Coolidge, Ivan R. Tomkins; Statesboro, Tulley Pennington; Thomasville, Leon Neel, H. L. Stoddard, Sr., George M. Sutton; Warner Robins, Mr. and Mrs. Thomas J. Cater, Jr.

From Illinois: 22-Blue Island, Karl E. Bartel; Catlin, Mary Baldwin, S. Glidden Baldwin; Champaign, Earle A. Davis, Jr.; Chicago, Muriel Beuschlein, Mr. and Mrs. A. L. Campbell, Constance Nice, L. B. Nice, Margaret M. Nice, Millicent Stebbins; Danville, Jack C. Blackman; Elsah, Norwood Hazard; Moline, Mr. and Mrs. Elton Fawks; Quincy, Edgert J. Long, O.F.M., Bro. Michael, Rozella M. Nichols; Springfield, Virginia S. Eifert; Urbana, Harvey I. Fisher, V. E. Shelford; Ursa, Mrs. Tom Sorrill.

From Indiana: 12-Centerville, Helen Cope, J. P. Cope; Fort Wayne, Margaret Umbach; Fremont, Mrs. R. R. Caswell; Hanover, Mr. and Mrs. J. Dan Webster; Indianapolis, Mildred Campbell, Mrs. S. G. Campbell; Richmond, Richard Myers, Mr. and Mrs. C. S. Snow, Charles Thaeler, Jr.

From Iowa: 9-Davenport, Albia F. Hazard, N. C. Hazard, Dr. and Mrs. J. P. Leonard, Peter Petersen, Jr.; Iowa City, Dr. and Mrs. A. Klaffenbach, Dr. and Mrs. Peter P. Laude.

From Kansas: 1-Lawrence, Harrison B. Tordoff.

From Kentucky : 13-Louisville, Mr. and Mrs. Leonard C. Brecher, Helen G. Browning, Mr. and Mrs. Dulaney Logan, Mabel Slack, Mrs. F. W. Stamm, Mrs. Wm. B. Tabler, Audrey A. Wright, Mr. and Mrs. James B. Young; Valley Station, Donald Summerfield.

From Maryland: 5-Chevy Chase, Mr. and Mrs. Elting Arnold; Laurel, Chandler S. Robbins; Towson, Mr. and Mrs. R. D. Cole.

From Massachusetts: 3-Boston, Phoebe G. Arnold; Lincoln, Charles H. Blake; Wellesley, Lucy Fisher.

From Michigan: 47-Albion, Shirley Brady, Louise Canfield, Wm. B. Canfield, Clara Dixon, Mary Ertell, Joan Glass, Maureen Kennedy, Owen Perkins, Jim Turner; Ann Arbor, Andrew J. Berger, Dorothy Blanchard, Mr. and Mrs. H. W. Hann, Mrs. Reuben L. Kahn, Cecil Kersting, Mary McNeil, Robert M. Mengel, Mrs. Beryl W. Spencer, Haven H. Spencer, J. Van Tyne; Dearborn, Mrs. Harold A. Barber, Harriet Berytold Woolfenden; Detroit, Margaret G. Common; Grosse Pointe, Clarence 
J. Messner, Hazel W. Messner; Jackson, Hazel L. Bradley, Dr. and Mrs. W. Powell Cottrille, Robert A. Whiting; E. Lansing, Mr. and Mrs. George Wallace; Huntington Woods, Mr. and Mrs. Neil T. Kelley; Kalamazoo, Mr. and Mrs. H. Lewis Batts, Jr., Mr. and Mrs. C. B. Cook, Harold O. Wiles, Helen Wiles, Judy Wiles; Mt. Pleasant, Mabel Cuthbert, N. L. Cuthbert, Irene F. Jorae; Port Huron, Elizabeth Kiefer, Francis Kiefer; Whitmore Lake, Mrs. Jane S. Mengel; Ypsilanti, Esther Byers.

From Minnesota: 11-Duluth, Doris E. Bronoel, Joel K. Bronoel, Elaine Hofslund, P. B. Hofslund, Evelyn Putnam; Minneapolis, Lewis L. Barrett, Mrs. Miriam C. Barrett, Mr. and Mrs. W. J. Breckenridge, Theodora Melone, Vera E. Sparkes; Northfield, Olin Sewall Pettingill, Jr.

From New Jersey: 3-Tenafly, Betty Carnes, Verona, Mr. and Mrs. Alfred E. Eynon.

From New York: 12-Buffalo, Fairman Cumming, Harold D. Mitchell, Mildred D. Mitchell, Edward L. Seeber; Ithaca, Julia Temple Grinnell, Lawrence I. Grinnell, Kenneth C. Parkes; New York, Florence Page Jaques, Francis L. Jaques, Ernst Mayr; Pelham, Richard H. Pough; Waterloo, Jason A. Walker.

From North Carolina: 18-Bryson City, Mary Jenkinson; Chapel Hill, Mrs. R. Lynn Ganet, Mrs. H. W. Walters; Charlotte, H. V. Autry, Mrs. H. V. Autry, Jr., Sara Nooe, Mrs. George C. Potter, Kitty Sandifer; Durham, Mrs. Mary M. Guy; Lenoir, Mr. and Mrs. Chas. E. Lavin; Matthews, B. R. Chamberlain; Raleigh, Charlotte Hilton Green, Mr. and Mrs. Z. P. Metcalf, Robert Overing, T. L. Quay, Richard Weaver.

From Ohio: 15-Cleveland, Elsie Erickson, Adela Gaede, Lucille Mannix, Mildred Stewart; Columbus, W. L. Muhlbach; Delaware, William D. Stull; Solon, Mr. and Mrs. Louis Sturm; Steubenville, Clinton S. Banks, Elizabeth Banks, Earl Farmer, Mr. and Mrs. Harry Graul; Toledo, Harold Mayfield, John M. McCormick.

From Pennsylvania: 7-Exton, Berrell E. Street, Phillips B. Street; Gettysburg, G. E. Grube; Pittsburgh, Anthony Netting, M. Graham Netting, Dana P. Snyder; York, K. V. Gardner.

From South Carolina: 8-Charleston, Mr. and Mrs. Ellison A. Williams; Clemson, Norma Pearson, Douglas Wade; Georgetown, William C. Grimm; Greenville, May W. Puett, McClellanville, Robert D. Edwards; Travellers Rest, Ruth Gilreath.

From South Dakota: 2-Sioux Falls, Mr. and Mrs. J. S. Findley.

From Tennessee: 57-Cookeville, Beulah Clark, Amy Johnson; Elizabethton, Dr. and Mrs. Lee R. Herndon, Dick Hughes, Mrs. Hugh Taylor; Franklin, Mrs. Elizabeth DeBrohun, Ruth White; Gatlinburg, Mr. and Mrs. Arthur Stupka; Knoxville, Hugh M. Davis, Jr., J. C. Howell, Don Hurley, John C. Jacobs, Jr., Reed Jenkins, Mr. and Mrs. W. M. Johnson, Richard R. Laurence, Mr. and Mrs. R. A. Monroe, Holly Overton, Bob Scott, William F. Searle, III, John Sonner, James T. Tanner, Isabel H. Tipton, Samuel R. Tipton, Mr. and Mrs. H. VanDeventer; Memphis, Frederick T. Carney, Mr. and Mrs. Ben B. Coffey, Jr., Nell Coleman, Tom Conley, Jr., Mary Davaut, Johnny Johnson, Frances E. Jones, Lawrence C. Kent, Harry Landis, Alice Smith, Demett Smith, Brother Leo Thomas; Nashville, Mrs. William Bell, Ruth Castles, Clara Williams Fentress, William E. Fentress, Albert F. Ganier, Mrs. Ernest Goodpasture, Frances Hagar, Mrs. F. C. Laskey, G. R. Mayfield, Jennie Riggs; Oak Ridge, Mrs. C. Brockney, Mr. and Mrs. R. J. Dunbar, Julia Moore, Barbara S. Thompson.

From Virginia: 6-Abingdon, Steve M. Russell, Harrisonburg, Hollen G. Helbert, 
Stanwyn G. Shetler, Milo D. Stahl; Norfolk, Mrs. Floy Burford; Richmond, Frederic R. Scott.

From West Virginia: 18-Huntington, R. M. Edeburn, Dorothy Fisher, N. Bayard Green, Ruth Hancer, Holwell K. Land, Hugh C. Land, Olive Mortison, Harry Peterson, David Pilkenton; Kimberly, M. J. Stahl; Morgantown, Robert L. Birch, Fred C. Brooks, Mr. and Mrs. Maurice G. Brooks, A. J. Dadisman, M. L. Hundley, Earl N. McCue; Sistersville, Mary B. Kimball.

From Wisconsin : 7-Madison, Mr. and Mrs. A. W. Schorger, Milwaukee, Helmut C. Mueller; Oshkosh, John L. Kaspar; Two Rivers, Winnifred Smith; Wausau, Herbert W. Levi; West Bend, Gerald A. Vogelsang.

From Ontario, Canada: 6-Pickering, Doris H. Speirs, J. Murray Speirs; Thistletown, Irma Metcalfe; Toronto, Olive Barfoot, W. W. H. Gunn, Douglas Scott Miller.

This number of The Wilson Bulletin was published on September 23, 1952. 


\section{$2 \mathrm{BHL}$ Biodiversity Heritage Library}

Mayfield, Harold F. 1952. "Proceedings of the Thirty-Third Annual Meeting." The Wilson bulletin 64(3), 186-192.

View This Item Online: https://www.biodiversitylibrary.org/item/215803

Permalink: https://www.biodiversitylibrary.org/partpdf/210741

\section{Holding Institution}

Harvard University, Museum of Comparative Zoology, Ernst Mayr Library

\section{Sponsored by}

IMLS LG-70-15-0138-15

\section{Copyright \& Reuse}

Copyright Status: In copyright. Digitized with the permission of the rights holder.

Rights Holder: Wilson Ornithological Society

License: http://creativecommons.org/licenses/by-nc-sa/4.0/

Rights: https://biodiversitylibrary.org/permissions

This document was created from content at the Biodiversity Heritage Library, the world's largest open access digital library for biodiversity literature and archives. Visit BHL at https://www.biodiversitylibrary.org. 